\title{
Research on Marketing Strategy of Electronic Components
}

\author{
Tao Cheng ${ }^{1, a, *}$ \\ ${ }^{1}$ Sichuan Institute of Solid State Circuits, China Electronics Technology Group Corp., \\ Chongqing 400060, P. R. China \\ a chengtao_24@126.com \\ *corresponding author
}

Keywords: 4P, 4C, electronic Components, marketing strategy.

\begin{abstract}
This article first introduces the development status of electronic components in China, then introduces the theory of marketing, and analyzes and compares the differences and relations between 4P and 4C theories. Finally, the marketing strategy of electronic Components are analyzed and put forward the key points of service marketing portfolio strategy.
\end{abstract}

\section{Introduction}

Electronic components industry in the modern industrial system occupy and its important role. The late 90s of last century, the electronic components industry in the United States has made considerable progress and progress, the electronic components were once considered by relevant scholars for the prosperity and development of other industries in the United States provided the basis for technical support.

With the development of the electronic components industry in the world, China's electronic components industry has also made considerable progress. A survey shows that from 2003 onwards, China's electronic components market grew at an average annual rate of more than 25\%. Especially in recent years, the rapid development of China's electronic information technology for electronic components manufacturers to provide further development opportunities, China's electronic yuan Device market to further expand the scope. Electronic components industry for the prosperity and stability of the national economy has made outstanding contributions. However, with the sweeping wave of economic globalization and due to the constant changes in the political and economic environment in the world, laws and regulations as well as the micro-environment in the enterprise and technological competition, China's electronic components industry is seriously challenged ${ }^{[1]}$.

At the same time, with the development of China's electronic information industry and the support of national industrial policies, the electronic components and parts industry, as the core component of electronic information products, is facing enormous opportunities and challenges. In the face of fierce competition and opportunities, whether our related enterprises are well prepared and formulated reasonable marketing strategies, which is very important for the survival and development of the company in the future..

\section{Theoretical Review of Marketing Strategy}

American Marketing Association (2005) Definition of Marketing: Marketing is an organizational function and procedure for creating, communicating and delivering value to customers and managing customer relationships in order to benefit the organization and its stakeholders.

\section{1. $\quad 4 P$ theory}

Namely "product”, “price”, "promotion”, and "place”. As E. Jerome McCarthy, a professor at the University of Michigan, put it in 1960, "Its greatness is that it simplifies marketing and facilitates memory and dissemination."

Products include core products, physical products and extended products. A broad product can 
be a tangible entity or an intangible service, technology, knowledge, or wisdom.

There are many price-making tools, competitive comparison method, cost plus method, target profit method and market gap method. The goal of these methods is to make the product an exchangeable commodity. Enterprises to profit as the goal, so pricing should take into account the efficiency of both sales and corporate effectiveness of the dual considerations, price war is a pricing and competitive strategy, but the price is not always effective, there was a friend who faced the same Olay A product in two different business selling price of different purchase options, one is to sell at full price, the other is to sell $20 \%$ off. The result is to choose the original price to buy. Information asymmetry, the price contains too much additional speculation information, quality, duration, authenticity, quality, utility, price is not only associated with the product itself, but also with the additional meaning and value of the brand is associated with the market supply and demand relationship associated with the reputation of the chosen shopping mall.

The traditional promotion is staff promotion, advertising, research activities and sales promotion. These ways in the marketing process has a very wide range of applications.

Channels are the sales path that products go from producer to consumer terminal. Ordinary consumer goods will go through the agents, wholesalers, shopping malls or zero link. B2C mode also has direct phone, TV direct sales, network direct sales, direct sales staff, store direct sales and other modes. The direct sales model greatly reduces the middle part of the process from manufacturer to buyer, compensating the intermediate profit for the consumer or generating the additional expense as a new marketing model.

\section{2. $4 \mathrm{C}$ theory}

With the increasingly fierce market competition, media transmission faster and faster, 4Ps theory is more and more challenged. In 1990, the American scholar Professor Robert Lauterborn put forward the 4P as opposed to traditional marketing Should 4Cs marketing theory. 4Ps marketing portfolio to the 4Cs marketing mix changes, specifically for the Production to Consumer shift, Price to Cost change, Place to Convenience change, Promotion to Communication change

\subsubsection{From "product" to "customer"}

In the 4Ps marketing mix, the product strategy is based on the target market positioning and customer needs made with the production product development related to planning and decision making. Its main content is: to meet the needs of users designed products features, production product quality standards, product features, packaging design, product brands and trademarks, sales and service, quality assurance, also package including product life cycle in various stages of the strategy. In the 4Cs marketing mix, customer strategy emphasizes business from the customer needs and interests, to produce products that meet the needs of consumers. So from the 4Ps "product" shift to 4Cs of the "customer", in fact, refers to the product development based on the business should pay more attention to consumer needs,to meet the consumer demand for profit, to achieve a winwin business and customers. This is a change in marketing concept, is recognized as the modern marketing of "the first revolution."

\subsubsection{From "price" to "cost"}

In the 4Ps marketing mix, the price strategy is the strategy that the enterprise realizes the product value, the pricing is the overall marketing one of the activities. The main basis for choosing a pricing strategy is the pricing target and the pricing guide. The main goal of business pricing to obtain the profit target and possession of the market target. In order to maintain and expand market share, enterprises should examine the market environment combined with its own strength, taking into account the immediate and long-term interests of enterprises at different times to develop different occupying the market set price target. In the 4Cs marketing mix, the cost strategy is the cost that the business considers the customer needs to meet when meeting the demand, rather than from the business point of view to achieve the profit target. From 4Ps "price" to 4Cs "cost",the shift is in effect the cost of changing a business from considering profitability goals to considering satisfying customer needs. 


\subsubsection{From "Place " to "convenience"}

In the 4Ps marketing mix, in the distribution channel strategy, companies should consider what kind of effective way to choose the product is transferred from the producer to the consumer. In the distribution channels, there are a series of institutions or individuals to participate in the second chapter of merchandise marketing strategy related theory summary of electronic components market small and medium-sized trading enterprises marketing exchange activities, they together constitute the orderly circulation of commodities. This kind of orderly link is the bridge linking production with consumption beams and ties. In the 4Cs marketing mix, the convenience strategy is that the firm considers the customer's purchase of goods in the distribution channel degree of convenience. From 4Ps " Place " to 4Cs "convenience" change, in fact, is based on their own business. there is a need to change to building distribution channels based on customer convenience.

\subsubsection{From "promotion" to "communication"}

In the 4Ps marketing mix, sales promotion is the one-way marketing information delivery to the customer, and the customer to the company the reaction of the promotion information can not be fed back to the enterprise, so it is difficult to achieve two-way communication and exchange between the enterprise and the customer. In 4Cs marketing mix, the communication strategy is between enterprises and customers bidirectional marketing communication, customer engagement to the enterprise product development and production.

Customer (customer) mainly refers to the needs of customers. Businesses must first understand and study customers, according to this. Customer needs to provide products. At the same time, businesses provide more than just products and services, but more importantly, they generate customer value.

Cost (Cost): not only the cost of production, or 4P Price (price), it also includes customers purchase costs, but also means that the ideal product pricing, it should be both below the psychological price of customers, can also make the company profit. In addition, the intermediate customer purchase costs include not only their monetary expenditures, but also it takes time, effort and effort, and the risk of buying.

Convenience: When a customer purchases a certain product, in addition to spending a certain amount of money, it costs one set the time, energy and physical, these constitute the total cost of customers. Therefore, the total customer cost includes the cost of money, when between costs, mental costs and physical costs. As customers in the purchase of goods, always want the relevant costs, including currency, time, mental and physical, etc. to minimize, so that they get the maximum satisfaction, therefore, the retail business will the "Total Cost of Customers" that customers are willing to pay to meet their needs must be considered. Efforts to reduce the total cost of customer purchases, such as reduce the cost of goods and marketing costs in order to reduce the price of goods in order to reduce the cost of customers money; efforts to mention high efficiency, minimize customer time expenditure, saving customers time to buy; through a variety of channels to customers provide detailed information to provide customers with a good after-sales service, reduce the spirit of customers and physical consumption communication is used instead of the corresponding Promotion in 4P. 4Cs marketing the theory holds that enterprises should establish positive and effective two-way communication based on common interests with customers industry /customer relationship. This is no longer a one-way business promotion and persuasion of customers, but in both the communication to find the same when to achieve their goals thoroughfare

\subsection{The Relationship between $4 \mathrm{P}$ Theory and 4C Theory}

As we all know, 4Ps and 4Cs are complementary rather than alternative relationship, that Customer refers to the use of "customer" to take

on behalf of the "product", we must first study the needs and desires of customers, and then go to the production, management and sales of customers to determine the service product you want to buy; Cost, which means replacing the "price" with "cost", knowing that the customer wants to meet its needs and desire to be willing to pay the cost, and then to develop pricing strategy; Convenience, 
refers to the "convenience" instead of "to point "means that as far as possible to develop customer strategy for the distribution strategy; Communication, refers to the use of" communication " replace "promotion", "communication" is two-way, "promotion" whether it is to promote the strategy or driving strategy, are linear propagation mode.

\section{Electronic Device Marketing}

Electronic device service marketing delivery system is divided into customer behavior, front service behavior, back-end service behavior and physical display from the horizontal direction, vertically divided into four stages: customer stage, customer stage, customer stage, and customer stage More, and some links include several small links, for the service delivery system, where only important aspects of design, for those aspects that we have to be clear. From the horizontal division point of view, there are two aspects in the customer behavior is very important, but also the service marketer must understand the important content of the customer, that is, the customer's needs and customer satisfaction, and identify customers in the front service behavior Demand and customer satisfaction assessment is the key link in service marketing portfolio strategy, service recovery and customer relationship management is the focus, and physical display is an important aspect of the company's hardware strength is a very important part. However, from the perspective of vertical division, in the process of obtaining customers and satisfying customers, we must first know the needs of customers and identify them, and then take targeted service marketing strategies based on the needs of customers, in which tangible shows are service marketing strategy Important aspects, then implement strategy and understand customer satisfaction. In the process of retaining customers and strengthening customers, due to the long span of time, service mistakes will inevitably occur. Therefore, service recovery has become an important link. After the remedy, we still have to understand the customer's satisfaction while understanding the new needs of the customers. The same procedure, the degree of difference only, and finally long-term customer satisfaction, customer relationship must be managed as the implementation of the object.

\subsection{Needs Analysis of Electronics Customers}

Electronic Components on the market of different customers, different stages of service, customer needs are different, to understand the real needs of customers is to narrow the gap between the quality of service key. The main sources of customer demand are two types, one is from the internal demand for value, the other is mainly driven by external stimuli demand.

\subsection{Identify customer needs}

Marketing How to understand the real needs of customers and guide the needs of customers is very important, some customers contact the company, claiming to be buying the company's electronic products, providing some product information, asking for a quote, in this case marketers must figure out whether Why customers are buying, perhaps treating you as a tool to keep their existing suppliers under pressure, is not necessarily about bringing you in. In order to understand the real needs of customers or customer value demands, can take the following approach
(1) face to face contact and communication
(2) good relationships
(3) integrated logical reasoning

\subsection{Electronic device marketing strategy}

Electronic device service marketing portfolio elements of quality, price, delivery, service, different customers, service marketing in different stages, the basis for decision-making is not the same,

\subsubsection{Customer Value Analysis}

The company has contact with customers, through the initial understanding of customers and require customers to provide customers industry-related data analysis to see if the customer's 
current situation to meet the company's market positioning and requirements, not all customers households have to do, depends on the value of our customers, customer value analysis includes basic customer information (customers name, location, the nature of the enterprise, business scope, size), customer management status (what is the main production and management product, product scale of operation, position in its counterparts, market positioning, future development strategy for customers and intent, and future needs, etc.), customer operational risk (how the customer's funds are, and what the terms of the payment are).

\subsubsection{Competitor analysis}

Take that kind of service marketing mix strategy with the situation of competitors, to try to understand the feelings of competitors status: Name of competitor, location, nature of enterprise, scope of business, size, status in its peers, the relationship with the customer, who has the best relationship with the customer, currently offers price, quality, delivery, including existing competitors and potential competitors

\subsubsection{Analyze its own power}

Only know ourselves, to know yourself, we have to analyze their own capabilities, marketing decision support system the system provides relevant support data to understand the quality, cost, delivery, and availability of your own product with the amount of circumstances, to facilitate the use of strategies,

\subsubsection{Service marketing portfolio strategy}

Service marketing portfolio strategy to take what strategy depends on the competitors, the needs of customers, our own depending on the ability of the situation, different service marketing stage is also different. Service portfolio elements in the implementation is divided into high, average, low three levels. General product quality and delivery regardless of level (quality and delivery period can be increased for the customer's request, they are basically determined by the market positioning and geographical location)

\section{Conclusion}

This article first introduces the development status of electronic components in China, then introduces the theory of marketing, and analyzes and compares the differences and relations between 4P and 4C theories. Finally, the marketing strategy of electronic Components are analyzed and put forward the key points of service marketing portfolio strategy.

\section{References}

[1] Joseph M. Bonner. Insustrial Marketing Management[M].2007,6:1094-1103.

[2] Young Ae Kim, Hee Seok Song, Soung Hie Kim. A new marketing strategy map for direct marketing. Knowledge-Based Systems[J], 2009, 22(5): 327-335.

[3] Leonidas C Leonidou, Constantine S Katsikea, Saeed Samiee. Marketing strategy determinants of export performance: a meta-analysis. Journal of Business Research[J], 2002, 55(1): 51—67.

[4] Henrikki Tikkanen,Jaakko Kujala,Karlos Artto. The marketing strategy of a project-based firm: The Four Portfolios Framework. Industrial Marketing Management[J], 2007, 36(2): 94-205. 